\title{
A szociális farmszolgáltatást igénybe vevő fogyatékos és megváltozott munkaképességủ személyek alapjogi védelme
}

\author{
The Protection of Fundamental Rights of People with Disabilities \\ and Reduced Capacity to Work Using Social Farm Services
}

\begin{abstract}
ABSZTRAKT
Jelen tanulmány a szociális farmszolgáltatást igénybe vevő hátrányos helyzetü személyeket - azok közül is kifejezetten a fogyatékos és megváltozott munkaképességủ személyeket - megilletô azon alapjogokat vizsgálja, melyek elengedhetetlenek számukra foglalkoztatásuk biztosítása érdekében. Ezek az emberek nagyon gyakran kiszorulnak a munkaerö-piacról, sőt meg sem tudnak jelenni ott. Ezért bírnak nagy jelentőséggel számukra az Alaptörvényben biztositott alapjogok, melyek lehetővé teszik ezeknek az embereknek (is), hogy egyenlöen bánjanak velük, és lehetöséget kapjanak a foglalkoztatásra. Az alkotmányos védelem megvalósulását továbbá munkajogi és szociális jogi jogszabályok is megerősítik.
\end{abstract}

Kulcsszavak: hátrányos helyzet, alapjogi védelem, egyenlö bánásmód, munkához való jog, fogyatékos személyek, megváltozott munkaképességủ személyek

\begin{abstract}
The present study examines the fundamental rights of disabled people using the service of social farms - especially people with disabilities and with reduced capacity to work. These rights are essential for these people in order to ensure their employment. These people are often cut off from the labour market, moreover, they cannot be present there. Therefore, fundamental rights ensured within the Fundamental Law of Hungary play a significant role for treating and employing them equally. Labour law and social law protection confirms this constitutional protection.
\end{abstract}

Keywords: disadvantage situation, protection of human rights, equal treatment, right to work, disabled people, people with reduced capacity to work

A hátrányos helyzet olyan sokrétű fogalom, amely értelmezhető egyének, csoportok vagy területi egységek, illetve gyermekek és felnőttek vonatkozásában is (például valamilyen fogyatékossággal élők, alacsony iskolai végzettségüek, oktatási esélyegyenlőség szempontjából hátrányos helyzetű gyermekek, elzárt és periférikus földrajzi területek, elvándorlással sújtott térségek, büntetés-végrehajtásból szabadulók stb.). Általánosságban véve a hátrányos helyzetnek nincs egységesen használt fogalma, definíciója. Jelentése úgy írható körül, hogy az átlaghoz viszonyítva rosszabb

\footnotetext{
*Dr. Orosz Flóra, kutató, Mádl Ferenc Összehasonlító Jogi Intézet, Budapest; e-mail: flora.orosz@mfi.gov.hu.
} 
gazdasági és szociális helyzetben lévő egyénekről, területekről van szó, akik, illetve amelyek helyzetének javítása, támogatása az államtól aktív szerepvállalást igényel. ${ }^{1}$ Azonban, ha konkrétan az egyének, méghozzá a gyermekek és felnőttek (munkavállalók) vonatkozásában vizsgáljuk a fogalmat, akkor a hátrányos (és halmozottan hátrányos) helyzetủ gyermek fogalmát a gyermekvédelmi törvény² 67/A.§-a, a hátrányos (és súlyosan hátrányos) munkavállaló fogalmát pedig a foglalkoztatási törvény ${ }^{3}$ 57/B.§ (4) bekezdés 1-2. pontja meghatározza. Magyarországon a hátrányos helyzet az egyes szakpolitikákat tekintve három területen jelenik meg: a munkaerőpiac, a területfejlesztés és az oktatáspolitika területén. Jelen tanulmány a munkaerő-piaci szempontból hátrányos helyzetü személyekre fókuszál, azon belül is a fogyatékos és megváltozott munkaképességü személyek védelmére, esélyegyenlőségük és foglalkoztatásuk biztosítása kapcsán.

A tanulmány apropóját a szociális farm modelljének vizsgálata adta, amellyel már régóta foglalkozom. Ennek egy szegmensét veszem górcső alá jelen tanulmány keretében, nevezetesen a szociális farmszolgáltatás célcsoporti köre relációjában érvényesülő és érvényesítendő, emberi jogi védelmi garanciákat. A szociális farm fogalmán, illetve a szociális farmszolgáltatáson keresztül mutatom be a hátrányos helyzetü személyek egyes csoportjának védelmére vonatkozó rendelkezéseket. A védelem körét az érintettek foglalkoztatásából kiindulva vizsgálom, amely bár öszszetett kérdés, és több jogterületet felölel, - így támogatási, finanszírozási és más területeket is - azonban kizárólag az ahhoz kapcsolódó alkotmányjogi, munkajogi és szociális jogi védelmet elemzem. A tanulmány leíró, elemző jellegű jogtudományi módszerekkel alkotmányjogi, munkajogi, szociális jogi és agrárjogi jogterületek elemzését ötvözi.

\section{A szociális farm modellje}

A szociális farm modellje olyan, innovatív mezőgazdasági tevékenységi formát jelent, amely valódi társadalmi és gazdasági jelentőséggel bír. Társadalmi súlyát az adja, hogy társadalmunk nagy hányadát érintő problémát, a hátrányos helyzetben élők mentális körülményeit és foglalkoztatási lehetőségeit javítja. Gazdasági fontossága pedig abban rejlik, hogy a célcsoporti kör tagjai mezőgazdasági tevékenységeket végeznek a farmon, amely tevékenységek által egyben foglalkoztatásuk is megvalósul. A farm tehát az a színtér, ahol a hátrányos helyzetü személyek aktívan bevonhatók a reintegrációs foglalkoztatásba. Mindezek alapján a szociális farm fogalma akként határozható meg, hogy az egy olyan multifunkcionális mezőgazdasági tevékenységi forma, amely a hagyományos agrártevékenységeken (gazdasági funkció) túl fontos társadalmi és ökológiai funkciót is ellát. ${ }^{4}$ Hangsúlyozni szüksé-

${ }^{1}$ Lásd a Wikipédia szócikkét: https://hu.wikipedia.org/wiki/H\%C3\%A1tr\%C3\%A1nyos_helyzet (2020. 11. 25.).

${ }^{2}$ A gyermekek védelméről és a gyámügyi igazgatásról szóló 1997. évi XXXI. törvény.

${ }^{3}$ A foglalkoztatás elősegítéséről és a munkanélküliek ellátásáról szóló 1991. évi IV. törvény.

${ }^{4}$ Orosz Flóra: Társadalmi felelősségvállalás a mezőgazdaság keretei között - különös tekintettel a nyugateurópai megoldásokra. In: Haffner Tamás (szerk.): IV. Fiatalok Európában Konferencia - Tanulmánykötet. Sopianae Kulturális Egyesület, Pécs, 2018, 221. 
ges, hogy a farm esetében nem elkülönült szervezeti formáról, hanem tevékenységi formáról beszélünk, amely alapvetően bármely szervezeti formában müködhet. ${ }^{5}$ A multifunkcionális farmok több vonatkozásban is túllépnek a hagyományos gazdaságokon. Kiszélesítik, elmélyítik, és új alapokra helyezik tevékenységeiket, kapcsolatrendszerüket. Az agrárium szociális szerepe a mezőgazdasági tevékenységeken kívül számos más funkcióra is kiterjed. Így például munkát ad, integrálja a hátrányos helyzetűeket (szociális és foglalkoztatási szempontból), egyben hagyományokat őriz, gondozza a vidéki tájat stb. ${ }^{6}$ Ez jelenti a szociális farmszolgáltatás rendszerét és lényegét. Két pillérre épül tehát a modell: a mezőgazdasági tevékenység végzésére és a támogató szolgálatra. Az alapkövet maga a farm képezi, amely biztosítja a farm szolgáltatásait igénybe vevőknek a biztonságos, helyreállító környezetben való készségfejlesztést, rehabilitációt, integrációt, s mindezt a mezőgazdaság keretein belül, mezőgazdasági tevékenységek által. Ezzel a farm célja a célcsoporti kör foglalkoztatása, a munkalehetőség biztosítása, és ezen keresztül pedig az, hogy ezek az emberek is a társadalom, illetve a munkaerő-piac aktív, teljes értékű tagjaivá válhassanak.

\subsection{A szociális farmszolgáltatást nyújtó farmok típusai}

A hazai ismeretek alapján a szociális farmszolgáltatást nyújtó farmok három típusát különböztethetjük meg: rehabilitációs farm, gondoskodó farm és társadalmi farm. $E$ három típus a célcsoporti kör és a szolgáltatásnyújtás jellege alapján különíthető el egymástól. A rehabilitációs farm a rehabilitáció helyszínéül szolgál, ahol a szociális farmszolgáltatás terápiás jellege irányadó. Ez a farmtípus azokat a speciális, támogatásra szoruló, hátrányos helyzetű személyeket fogadja, akik segítség nélkül nem képesek helyzetükön javítani, de a farmon való aktív bevonás elősegíti fejlődésüket, rehabilitációjukat. A célcsoportba elsősorban a fogyatékossággal élők tartoznak, akik számára különösen fontos a rehabilitáció, társadalmi integráció. Müködési szempontból két csoportja van a rehabilitációs farmnak. Az egyik csoportba tartoznak azok az érintetteket gondozó, segítő intézmények, szervezetek, melyek maguk szervezik meg a szociális farmszolgáltatást. A másik esetben a rehabilitációs farmer által müködtetett, fogadó gazdaság biztosítja a helyszínt a farmszolgáltatáshoz,

\footnotetext{
${ }^{5}$ Alkalmasnak bizonyuló szervezeti formák: a) őstermelő, egyéni vállalkozó, családi gazdaság; b) szövetkezet, civil szervezet, egyházi jogi személy stb. A szociális farm lehetséges jogi formájáról bővebben lásd ORosz Flóra: A mezőgazdasági tevékenység végzésének feltételei és korlátai - szervezeti és pénzügyi keretek. Publicationes Universitatis Miskolcinensis Sectio Juridica et Politica, 2019/2, 416-432.

${ }^{6}$ CsÁk Csilla: Szociális inklúzió megvalósulása a szociális farmrendszer keretei között. In: Veresné Somosi Mariann-Lipták Katalin (szerk.): „Mérleg és Kihívások” IX. Nemzetközi Tudományos Konferencia. A Gazdaságtudományi Kar megalapításának 25. évfordulója alkalmából. ME GTK, Miskolc, 2015, 1-10.; CsÁk CsillaKENDERES György: Hátrányos helyzetű személyek foglalkoztatási lehetőségei és annak bizonytalanságai a mezőgazdaságban. In: Homoki-Nagy Mária-Hajdú József (szerk.): Ünnepi kötet Dr. Czúcz Ottó egyetemi tanár 70. születésnapjára. SZTE ÁJK, Szeged, 2016, 145-152.; CsÁk Csilla-KENDERES György: New organizational and employment opportunities of the multifunctional agriculture. In: Kékesi Tamás (szerk.): The Publications of the MultiScience $-X X X$. microCAD International Multidisciplinary Scientific Conference. University of Miskolc, Miskolc, 2016, 1-11.
} 
ahol a gazda ismeretekkel rendelkezik a bevonandó célcsoport rehabilitációjához. A gondoskodó farm típusánál már intenzíven megjelenik az érintettek munkára való ösztönzése, akik ténylegesen dolgoznak a farmon. Ez a farmtípus föként a megváltozott munkaképességüeket és tartós munkanélkülieket foglalkoztatja. Gondoskodó farmot, a bevont célcsoporttól függően, müködtethetnek gazdák és szociális szolgáltatók is. A harmadik típusnál, a társadalmi farmon szemléletformálás és ismeretátadás történik. Itt a célcsoport tagjai megismerkedhetnek a mezőgazdasági munkálatokkal, munkafolyamatokkal, elsajátíthatják azokat, illetve ez a farmtípus elősegíti a résztvevők mások iránti elfogadását, a velük való együttlétet, együttmüködést, az életben való könnyebb boldogulást. A célcsoportokban nem mentális vagy fizikai hátránnyal küzdők szerepelnek, hanem egészséges emberek. Közcélú munkára ítéltek, menekültek, romák, mélyszegénységben élők, gyermekvédelmi intézményekből kijövők, és legfőképpen oktatási-nevelési intézményekben tanulók gyerekek és diákok. ${ }^{7}$

A tanulmány a fent megnevezett három farmtípus célcsoporti köre közül a rehabilitációs és gondoskodó farm elsődleges alanyi körére, a fogyatékos és megváltozott munkaképességủ személyekre kíván koncentrálni, az ő személyüket érintő alapjogi védelmet vizsgálja. A fogyatékos és megváltozott munkaképességü személyekről, illetve egyáltalán a fogyatékos és megváltozott munkaképes helyzetről azt a megállapítást tehetjük, hogy ezek az emberek másak, helyzetük más állapotot, körülményt eredményez. Ez nem azt jelenti, hogy ezeknek az embereknek az élete kevesebbet érne, hanem másság jellemzi őket. Másságuk révén sok szempontból segítségre szorulnak, például a foglalkoztatás esetén. A szociális biztonsághoz való jogból következően az állam feladata a szociális intézményrendszer kiépítése és működtetése. A munkához való jog tekintetében szintén az állam feladata, hogy megteremtse minden munkaképes és dolgozni akaró ember számára a munkavégzés feltételeit. Azonban vannak olyan területek, ahol a szociális ellátás nem megfelelő vagy hiányzik, illetve a munkavégzés lehetősége is korlátozott. llyen terület a fogyatékos és megváltozott munkaképességủ emberek társadalmi és foglalkoztatási integrációja. Ezeknek az embereknek a munkaerőpiacon való elhelyezkedése meglehetősen nehéz, sőt sok esetben egyáltalán nem kapnak rá lehetőséget. A szociális farm ezt az ürt hivatott betölteni, ezeket az embereket (is) igyekszik segíteni, ugyanis felkarolja ezt a személyi kört, és megfelelö mentális fejlődést, illetve munkavégzési lehetőséget biztosít számukra. Úgy vélem, azoknak az emberi jogoknak az érvényesülése, érvényesítése, melyek azt biztosítják a fogyatékos és megváltozott munkaképességủ személyek számára, hogy a társadalom és a munka világának is tagjai, részesei lehessenek, különösen is fontos esetükben - ha nem fontosabb a társadalom többi tagjához képest. Hipotézisem szerint a tanulmányban vizsgált emberi jogok és azok védelme megfelelő alapot ad arra, hogy ezeknek az embereknek is biztosítani kell a munkához való hozzáférést, az egyenlő bánásmódot.

7 JAKUBINYI László: A szociális farm fogalma és típusai. In: Kajner Péter-Jakubinyi László (szerk.): Szociális farmok létrehozása Magyarországon. Szimbiózis Alapítvány, Miskolc, 2015, 30-31. 


\subsection{A fogyatékos és megváltozott munkaképességü személyek fogalma}

A megnevezett védelmi célterületek tárgyalását megelőzően tisztázásra szorul a fogyatékos és megváltozott munkaképességủ személyek fogalma. A fogalmi tisztánlátás elsősorban a foglalkoztatás jogi kérdései kapcsán bír jelentőséggel. A két fogalmat gyakran szinonimaként kezelik, elméletben és gyakorlatban egyaránt, azonban a két fogalmat el kell egymástól határolni. A hazai terminológia kifejezetten meg is különbözteti a fogyatékos személy és a megváltozott munkaképességű személy fogalmát - szemben az Európai Unió más országaival, ahol a „person with disability” (fogyatékos személy) fogalmat használják mindkét esetre. A két fogalom jelentése halmaz-részhalmaz viszonyban áll egymással, ahol a megváltozott munkaképességủ személyek a fogyatékos személyek halmazának részét képzik. ${ }^{8} \mathrm{~A}$ fogyatékos személyt valamilyen bekövetkezett károsodás akadályozza a társadalomban és a foglalkoztatásban való részvételében, a megváltozott munkaképességű személy pedig a munkaerőpiacon szerzett valamilyen, maradandó egészségkárosodása folytán korlátozott a munkavégzésben. ${ }^{9}$

A nemzetközi jog, az Európai Unió tagállamainak joga és a magyar jog eltérően határozza meg a fogyatékossággal élő személy fogalmát. A fogyatékossággal élő személyek jogairól szóló ENSZ egyezmény ${ }^{10} 1$. cikke a következőképpen fogalmazza meg a fogyatékosság fogalmát: „Fogyatékossággal élő személy minden olyan személy, aki hosszan tartó fizikai, értelmi, szellemi vagy érzékszervi károsodással él, amely számos egyéb akadállyal együtt korlátozhatja az adott személy teljes, hatékony és másokkal egyenlő társadalmi szerepvállalását." Ez a definíció egy egységes fogalom alatt, exemplifikatív felsorolással magában foglal mindenféle szempontból bekövetkezett károsodásokat. Az Európai Unió tagállamainak fogalomhasználatát tekintve Jakab Nóra és Kajtár Edit az Empower Projectben végzett kutatómunkájuk eredményeként megállapították, hogy a környező kelet- és nyugat-európai országok jogszabályai a fogyatékossággal élő ember kifejezést alkalmazzák. ${ }^{11}$

Ezzel szemben a magyar jogi szabályozás és terminológia sajátossága az, hogy a fogyatékosság-fogalmon belül elkülöníti a) a fogyatékos személy és b) a megváltozott munkaképességủ személy fogalmát, amely fogalmakkal kapcsolatos rendelkezéseket külön törvény szabályozza. A fogyatékos személy fogalmát az 1998. évi XXVI. törvény ${ }^{12}$ határozza meg: „az a személy, aki tartósan vagy véglegesen érzékszervi, értelmi, fizikai, kommunikációs károsodással él, amely az egyelö társadalmi

\footnotetext{
8 JAKAB Nóra: A fogyatékosság szociálpolitikai összefüggései. In: Mélypataki Gábor (szerk.): A szociálpolitika jogi alapjai a XXI. század társadalmi kihívásainak tükrében. Bíbor Kiadó, Miskolc, 2017, 205-209.

${ }^{9}$ Prugberger Tamás-Jakab Nóra: A foglalkoztatás elősegítés és igazgatás joga. Bíbor Kiadó, Miskolc, 2016, 172-173.

${ }^{10}$ Convention on the Rights of Persons with Disabilitis. A/61/611, Distr.: General, 6 December 2006. https://www. un.org/esa/socdev/enable/rights/convtexte.htm (2020. 10. 10.)

11 JAKAB Nóra-KAJTÁR Edit-ZELLER Judit: The Empower Project: International cooperation for persons with disabilities. Final Report. Pécsi Munkajogi Közlemények, 2013/1, 175-191.

${ }^{12}$ A fogyatékos személyek jogairól és esélyegyenlőségük biztosításáról szóló 1998. évi XXVI. törvény (a továbbiakban: Fogy. tv.)
} 
részvételt korlátozza vagy gátolja."13 A megváltozott munkaképességủ személy fogalmát az 1991. évi IV. törvény ${ }^{14}$ határozza meg:

„a rehabilitációs hatóság vagy jogelődjei által végzett hatályos minősítés alapján a) akinek az egészségi állapota a rehabilitációs hatóság komplex minősítése alapján 60 százalékos vagy kisebb mértékü, b) aki legalább 40 százalékos egészségkárosodással rendelkezik, az erről szóló szakvélemény, szakhatósági állásfoglalás, hatósági bizonyítvány alapján, c) akinek a munkaképesség-csökkenése 50-100 százalékos mértékü; vagy aki a komplex minősítés alól jogszabály rendelkezése alapján mentesül, rokkantsági ellátás folyósításának időtartama alatt."15

A két definíciót tekintve arra a megállapításra juthatunk, hogy míg a megváltozott munkaképességű személyek munkaerő-piaci esélyei az egészségi állapot leromlása miatt romlottak meg, akik egy biztosítási jogviszonyhoz kötődő kategóriát képeznek, addig a fogyatékossággal élő emberek nagy része meg sem jelenik a munkaerőpiacon, így biztosítási jogviszonnyal sem rendelkezik. ${ }^{16}$

\section{A célcsoporti körre vonatkozó alkotmányjogi védelem}

A fogyatékos és megváltozott munkaképességű személy fogalmának tisztázását követően a célcsoporti kör védelmének vizsgálatát a jogforrási hierarchia legmagasabb szintű jogszabályával, az Alaptörvénnyel szükséges és célszerü kezdeni, hiszen a munkajog és szociális jog által biztosított munkaeröpiaci védelmi rendelkezések gyökerei ezekre az alkotmányos rendelkezésekre vezethetők vissza, ezek az alkotmányos rendelkezések jelölik ki a védelem alkotmányos keretét. ${ }^{17} \mathrm{Az}$ Alaptörvény több cikke is tartalmaz közvetlenül vagy közvetve releváns, a fogyatékos és megváltozott munkaképességủ személyeket (is) megillető jogokat. Ezek a jogok nevezetesen az egyenlö bánásmód elve (megkülönböztetés tilalma), mint első generációs alapvető emberi jog, illetve a szociális biztonsághoz való jog és a munkához való jog, mint második generációs alkotmányos alapjogok.

Az első generációs alapjogokhoz tartoznak az úgynevezett klasszikus szabadságjogok, melyek az államhatalom korlátozását jelentik, azaz az államtól passzív magatartást, a jogok érvényesülésének túrését igénylik. Ide tartozik az állampolgárok egyenjogúságát biztosító egyenlő bánásmód elve is. Ezek a jogok alkotmányjogi védelemben részesülnek. ${ }^{18}$

${ }^{13}$ Fogy. tv. 4.§ a) pont.

${ }^{14}$ A foglalkoztatás elősegítéséröl és a munkanélküliek ellátásáról szóló 1991. évi IV. törvény (a továbbiakban: Fogl. tv.)

15 Fogl. tv. 58.§ $m$ ).

16 JAKAB Nóra: A munkavállalói jogalanyiság munkajogi és szociális jogi kérdései, különös tekintettel a megváltozott munkaképességű és fogyatékos személyekre. Bíbor Kiadó, Miskolc, 2015, 33-35.; JAKAB Nóra-MÉLYPATAKI Gábor-SZEKERES Bernadett: A szociálpolitika jogi alapjai a XXI. század társadalmi kihívásainak tükrében. Bíbor Kiadó, Miskolc, 2017, 205-209.

17 ZACCARIA Márton Leó: Az egyenlő bánásmód elvének érvényesülése a munkajog területén a magyar joggyakorlatban. HVG-ORAC, Budapest, 2015, 40-48.

18 SÁRI János-Somody Bernadette: Alapjogok, Alkotmányjog II. Osiris, Budapest, 2008. Lásd a Digitális Tankönyvtárban: https://regi.tankonyvtar.hu/hu/tartalom/tamop425/2011_0001_520_alapjogok_alkotmanytan_ii/ ch01s02.html (2020. 10. 11.) 
A második generációs emberi jogok az úgynevezett gazdasági, szociális és kulturális jogok, összefoglalóan szociális jogok, melyek a 19. század második felében fogalmazódtak meg, majd a 20. században nyertek alkotmányos védelmet. Azt a célt szolgálják, hogy az egyének a társadalom részesei lehessenek gazdasági, szociális és kulturális szempontból - így munkát vállalhassanak, egymással szervezkedhessenek, munkanélküliség esetén ellátásban részesüljenek, a tudományos és művészi életben szabadon kifejezhessék önmagukat stb. Ezek a jogok a klasszikus szabadságjogoktól alapvetően abban különböznek, hogy az állam gazdasági teljesítőképességétől függnek. Ha gazdaságilag jól teljesít az állam, szélesebb körben tudja a szociális jogokat biztosítani, szélesebb körű intézkedésekre van lehetősége. ${ }^{19}$ További különbség, hogy az állam részéröl ezek a jogok tevőleges magatartást igényelnek, azaz az alkotmány és alacsonyabb szintủ jogszabályok által biztosított jogi garancia mellett anyagi garanciára - a szociális jogok érvényesülését biztosító intézményi hálózatra, az intézményrendszer igénybevételi feltételeinek meghatározására és pénzügyi fedezetre - is szükség van, szemben az első generációs szabadságjogokkal, ahol az állam tartózkodni köteles azok érvényesülése érdekében. ${ }^{20}$ Ehhez kapcsolódóan az Alkotmánybíróság a 25/2016. (XII. 21.) AB határozat 20. pontjában utalt arra a szociális jogokkal kapcsolatban, hogy

„...az állam kötelezettségei alapvetően arra korlátozódnak, hogy egyrészt hozzon létre olyan intézményrendszert, amely útján az alkotmányos jogok érvényesülhetnek, másrészt pedig meg kell határoznia az intézményrendszer igénybevételével kapcsolatos jogosultságokat."

A szociális jogok Alaptörvényben való nevesítése az egyének - jelen tanulmány szempontjából kifejezetten a fogyatékos és megváltozott munkaképességú személyek - védelme mellett azt is szolgálja, hogy a jogalkotásnak és jogalkalmazásnak is tekintettel kell lenniük azokra. Így a jogalkotó nem alkothat az alkotmányban biztosított jogokkal ellentétes jogszabályokat, és a jogalkalmazás során sem kerülhető meg azok betartása. Mindezt az Alkotmánybíróság gyakorlata is kiegészíti és megerősíti, ami egyben az említett jogok pontos tartalmát is értelmezi, kijelöli. ${ }^{21} \mathrm{~A}$ második generációs alapjogok bár az egyéneket megillető, fontos jogosultságokat hordoznak magukban, amit az azokról rendelkező nemzetközi és uniós dokumentumok is alátámasztanak, - amelyek tárgyalása nem képezi e tanulmány részét - általánosságban véve a szociális jogok nem tekinthetők olyan erős alanyi jogoknak, mint az első generációs szabadságjogok. A gyengébb jogok esetében az alkotmányos védelem mértéke is kisebb. ${ }^{22} \mathrm{Az}$ alkotmányos védelem szociális jogok tekintetében

${ }^{19}$ BALOGH Zsolt: Szociális jogok. In: Schanda Balázs-Balogh Zsolt (szerk.): Alkotmány - Alapjogok. PPKE JÁK, Budapest, 2011, 307-308. [a továbbiakban: BALOGH (2011a)]

20 TÉGLÁSI András: A szociális állam „erodálása” vagy megmentése? - avagy a szociális biztonság az új Alaptörvényben. Jogelméleti szemle, 2011/4, 3-4.; KISs Barnabás: A szociális biztonság alkotmányjogi megítélése Magyarországon a rendszerváltozást követően. Acta Universitatis Szegediensis: Acta juridica et politica, 2016/1-64, 358.

${ }^{21}$ ZACCARIA: i. m., 48-50.

${ }^{22}$ A szociális jogok alkotmányos védelme tekintetében két modell különíthető el: a) az alkotmányon belül nem kell a szociális jogokat szabályozni, vagy ha szabályozva is vannak, akkor azok nem teremthetnek alanyi jogosultságot; $b$ ) a klasszikus szabadságjogok és a szociális jogok egymást feltételezik, oszthatatlanok. Rész- 
való vizsgálatakor nem mehetünk el amellett, hogy alapvetően a szociális jogok az alkotmányos védelem szempontjából három csoportba sorolhatók, amely kategorizálás a tanulmányban vizsgált két szociális jog esetében is jelentőséggel bír, mivel két eltérő csoportba tartozó, így eltérő jellemzőkkel bíró jogról van szó: a) alapjogok, b) alapjognak nem minősülő alkotmányos jogok, c) államcélok. ${ }^{23}$

A gyengébb alkotmányos védelem ellenére a fogyatékos és megváltozott munkaképességú személyek számára kifejezetten nagy horderejű jogokról van szó, - különös tekintettel a szociális biztonsághoz való jogra és a munkához való jogra hiszen ezek az emberek a társadalom többi tagjához képest nagyobb támogatásra, segítségre szorulnak, előnyben részesítést „szükséges” esetükben alkalmazni esélyegyenlőségi és munkavégzési korlátozottságuk révén. Ezek alapján e jogok jelentősége, annak folytán pedig elemzése megkerülhetetlen.

A bevezetőben említettek szerint a szociális farm modellje, mint tevékenységi forma, többféle szervezeti formában is müködhet. Ez felveti annak kérdését, hogy a különféle szervezeti keretek eredményeznek-e, és ha igen, milyen eltérést az alapjogi jogvédelem tekintetében. Az eltérő jogviszonyok különféle jellemzőkkel bírnak, amely heterogén jellegű foglalkoztatási viszonyt eredményez. Azonban a klasszikus alapjogi védelem ugyanúgy vonatkozik valamennyi jogviszonyra, ugyanúgy érvényesítendő mindegyik esetében. Kutatásom részét képezi a lehetséges szervezeti formák vizsgálata, amely azonban külön, a jogviszonyt elemző tanulmány témája, és nem vet fel alapjogi kérdést. A tanulmányban vizsgált, a fogyatékos és megváltozott munkaképességủ személyek - akik a szociális farmok speciális státuszú személyi körét alkotják - védelmének speciális jellegét nem a különböző foglalkoztatási jogviszonyok határozzák meg, hanem személyi állapotuk, azaz fogyatékosságuk és megváltozott munkaképességük. Esetükben a fö dilemmát az jelenti, hogy milyen jogosultsággal termelhetnek kisléptékben mezőgazdasági alapanyagokat, ezeket milyen jogosultsággal használhatják fel önellátási célra, illetve környezetükben ezt hogyan tudnák értékesíteni. Ennélfogva, a mezőgazdasági tevékenységre és a fogyatékos, megváltozott munkaképességre tekintettel sajátos jogvédelmi státusz kialakítása szükséges annak érdekében, hogy részt vehessenek a termelésben, felhasználhassák a termékeket, illetve értékesíthessék azokat, igénybe véve a más esetekben meglévő kedvezményeket. Ugyanakkor ennek a sajátos jogvédelemnek a bázisát a klasszikus alapjogi védelem képezi. Ennek nyomán, illetve valamennyi jogviszony esetében azonos alapjogi védelemre tekintettel, a továbbiakban a megjelölt célcsoport alapjogi védelme általánosságban kerül elemzésre.

\subsection{Az egyenlö bánásmód elve}

A XV. cikk rendelkezik az egyenlö bánásmód elvéröl, a diszkrimináció általános tilalmáról, ami a munkavállalói jogok és védett érdekek tekintetében is kiemelkedő

letesebben lásd BALOGH (2011): i. m., 305-306.; BALOGH Zsolt: Az értelmezés hatalma - szociális jogok az Alkotmányban. In: Hajas Barnabás-Schanda Balázs (szerk.): Formatori luris Publici. Ünnepi Kötet Kilényi Géza professzor hetvenedik születésnapjára. Szent István Társulat, Budapest, 2006, 25-37.

${ }^{23}$ BALOGH (2011a): i. m., 308. 
szerepet tölt be, ugyanis a különböző jogágakon belül megjelenő hátrányos megkülönböztetés markánsan jelenik meg a munkajogban. A korábban hatályos Alkotmányhoz hasonlóan az Alaptörvény is két irányból közelíti meg az embereket megillető egyenlőséget: a) egyrészt kimondja, hogy a törvény előtt mindenki egyenlö, ${ }^{24}$ másrészt $b$ ) tiltja a hátrányos megkülönböztetést, ${ }^{25}$ azaz az alapvető jogokat mindenkinek bármely megkülönböztetés nélkül biztosítja. ${ }^{26}$ Fontos megjegyezni az egyenlőség tekintetében, hogy el kell határolni a társadalmi életben vett egyenlöséget a jogi értelemben vett egyenlő bánásmód elvétől. Míg az előző értelemben ugyanis az egyenlőség alkotmányjogi szemszögből nem értelmezhető, addig a másik értelemben az alkotmányjog által védelemben részesített egyenjogúságról van szó. ${ }^{27}$ Számunkra, a tanulmány célja tekintetében a jogilag védett egyenjogúság bír jelentőséggel. A jogi értelemben vett egyenlő bánásmód elvének megsértése, azaz a diszkrimináció mindig valamilyen jog vagy kötelezettség tekintetében értelmezhető: „... valamely jog megvonásában vagy másokat nem terhelő kötelezettség megállapitásában kell megtestesülnie, csak így válik jogilag relevánssá." ${ }^{28}$ Továbbá, mint a 9/2016. (IV. 6.) AB határozat 84. pontja kimondja,

\begin{abstract}
„Az Alkotmánybíróság állandó gyakorlata szerint személyek közötti, alkotmánysértö hátrányos megkülönböztetés akkor állapítható meg, ha valamely személyt vagy embercsoportot más, azonos helyzetben lévő személyekkel vagy csoporttal történt összehasonlitásban kezelnek hátrányosabb módon. A megkülönböztetés pedig akkor alkotmányellenes, ha a jogszabály a szabályozás szempontjából azonos csoportba tartozó (egymással összehasonlítható) jogalanyok között tesz különbséget anélkül, hogy annak alkotmányos indoka lenne."
\end{abstract}

Az Alaptörvény XV. cikk (2) bekezdése példálózó jelleggel sorolja fel azokat az eseteket, amelyek alapján való megkülönböztetés diszkriminációt valósít meg. A felsorolás kapcsán a 3206/2014. (VII. 21.) AB határozat 27. pontja akként rendelkezik, hogy

„... a diszkriminációtilalom alkotmányos klauzulája elsődlegesen a társadalom személyben rejlő és tetszés szerint nem változtatható tulajdonság mentén elkülönülő csoportjainak védelmét szolgálja. ....a rendelkezésben említett tulajdonságok - faj, szín, nem, fogyatékosság, társadalmi származás stb. - az egyén megváltoztathatatlan tulajdonságai, amelyeket nem tud befolyásolni."

A felsorolt esetek, személyböl fakadó tulajdonságok között tehát a fogyatékosság, kifejezetten nevesített esetként, védett tulajdonságnak minősül az egyenlő bánásmód biztosítása körében. A fogyatékossággal a fogyatékos embereknek együtt kell

\footnotetext{
${ }^{24}$ Bár az Alkotmány nem tartalmazta a „mindenki egyenlő” rendelkezést, Alaptörvényünk XV. cikkének (1) bekezdése már tartalmazza ezt a fordulatot.

25 45/2000. (XII. 8.) AB határozat, ABH 2000, 344.

${ }^{26}$ 9/2016. (IV. 6.) AB határozat.

${ }^{27}$ KIss Barnabás: Az egyenlő bánásmód elvének és a hátrányos megkülönböztetés tilalmának jogi szabályozása. Acta Universitas Szegediensis: Acta Juridica et Politica, 2003/12, 5-6.

${ }^{28}$ 45/2000. (XII. 8.) AB határozat, ABH 2000, 344, 3.2. pont.
} 
élniük, azon változtatni nem tudnak, azonban az alapvető jogok őket is megilletik. Továbbá a fogyatékossággal élő személyek köre külön is kiemelt, különleges gondoskodásra szoruló, védelmet igénylő csoportnak minősül, akik esélyegyenlősége és társadalmi felzárkózása érdekében Magyarországnak az (5) bekezdés szerint külön intézkedéseket is kell foganatosítania. Ilyen intézkedésnek minősült, amikor az Emberi Erőforrások Minisztériumán belül létrehozták a Társadalmi Felzárkózásért Felelős Államtitkárságot. Valamint az állam annak érdekében, hogy hatékony jogvédelmet biztosítson a hátrányos megkülönböztetést elszenvedők számára, külön intézményt, az Egyenlö Bánásmód Hatóságot ${ }^{29}$ hozta létre. ${ }^{30}$

A diszkrimináció esetében azonban meg kell jegyezni, hogy az nemcsak hátrányos lehet, melyet az Alaptörvény tilt, hanem pozitív is. Kivételesen ugyanis el lehet térni az általános tilalomtól, de csak amennyiben az az egyenlőség tartalmi megvalósulását szolgáló pozitív megkülönböztetés. Tehát nem minden különbségtétel tilalmazott, hanem csak az igazolható ok nélküli megkülönböztetés, és amely sérti az emberi méltóságot. ${ }^{31}$ Ezt erősítette meg az Alkotmánybíróság a 9/1990. (IV.25.) AB határozat IV. pontjában, amikor kimondta, hogy

„... a diszkrimináció tilalma nem jelenti azt, hogy minden, még a végső soron nagyobb társadalmi egyenlöséget célzó megkülönböztetés is tilos. A megkülönböztetés tilalma arra vonatkozik, hogy a jognak mindenkit egyenlőként (egyenlő méltóságú személyként) kell kezelnie, azaz az emberi méltóság alapjogán nem eshet csorba, azonos tisztelettel és körültekintéssel, az egyéni szempontok azonos mértékü figyelembevételével kell a jogosultságok és a kedvezmények elosztásának szempontjait meghatározni. ...De ha valamely - az Alkotmányba nem ütköző - társadalmi cél vagy valamely alkotmányos jog csakis úgy érvényesíthető, hogy e szűkebb értelemben vett egyenlőség nem valósítható meg, akkor az ilyen pozitív diszkriminációt nem lehet alkotmányellenesnek minősíteni."

\subsection{A szociális biztonsághoz való jog}

Az Alaptörvény XIX. cikke szabályozza a szociális biztonsághoz való jogot. Szociális biztonság alatt azt az élethelyzetet értjük, amikor az emberek létfenntartása, megélhetése megfelelöen biztosított. Olyan életminőség, amely a jólétet feltételez. Takács Albert értelmezése szerint „,...az emberi élet olyan minősége, amely a jóléttel összefüggésben értelmezhetö." ${ }^{32}$ Akkor kell érvényesíteni, amikor a munkavégzés

${ }^{29}$ A Hatóság az egyenlő bánásmódról és az esélyegyenlőség előmozdításáról szóló 2003. évi CXXV. törvény értelmében jött lére, melynek feladata annak ellenőrzése, hogy érvényesül-e az egyenlő bánásmód követelménye.

${ }^{30}$ Az Alaptörvény XV. cikkének indoklása; a CompLex Jogtár kommentárjának e cikkhez írt indoklása; a Kúria joggyakorlat-elemző csoportjának véleménye - Az egyenlő bánásmód követelményének megsértésével kapcsolatos munkaügyi bírósági gyakorlatban foglaltak.

${ }^{31}$ BALOGH Zsolt: A diszkrimináció tilalma. In: Schanda Balázs-Balogh Zsolt (szerk.): Alkotmányjog-Alapjogok. PPKE JÁK, Budapest, 2011, 137-140. [a továbbiakban: BALOGH (2011b)]

${ }^{32}$ TAKÁcs Albert: Szociális jogok az Alkotmányban és a munka alkotmányjogi szerepe. In: Molnár BorbálaGyombolai Zsolt-Téglási András (szerk.): Gazdasági alapjogok és az új magyar Alkotmány. Az Országgyülés Emberi jogi, kisebbségi, civil- és vallásügyi bizottsága, Budapest, 2011, 79. 
és az abból származó jövedelem, valamint maga a munkavégzési képesség, valamely előre nem látható körülmény, kockázat miatt átmenetileg vagy tartósan korlátozódik, szünetel, vagy véglegesen megszünik. Ennek megfelelően, Hajdú József úgy ítéli meg, hogy a szociális biztonsághoz való jog szubszidiárius a munkához való joghoz képest, ${ }^{33}$ vagyis a szociális biztonsághoz való jog akkor nyer jelentőséget, ha a munkához való jog megszünik.

A szociális biztonsághoz való jog az alkotmányos védelem intenzitását tekintve a második csoportba, vagyis az alapjognak nem minősülő alkotmányos jogok közzé tartozik. Az e csoportba tartozó jogok sajátossága, hogy esetükben az alkotmányos rendelkezésekből nem ered közvetlen alanyi jogosultság, kizárólag az alkotmány alapján nem lehet azokat érvényesíteni, hanem érvényesülésüket a jogalkotónak kell további törvényi szabályozás által biztosítania. ${ }^{34}$

Az alaptörvényi rendelkezés elemzését megelőzően megjegyzést érdemel, hogy e jog tekintetében az Alaptörvény XIX. cikkének szabályozása változást, új szemléletmódot hozott az Alkotmány 70/E. §-ához képest. ${ }^{35}$ A XIX. cikk (1) bekezdése Magyarország azon törekvését rögzíti, hogy minden magyar állampolgárnak szociális biztonságot biztosítson. Ez a fordulat hozta az egyik leglényegesebb változást azáltal, hogy az Alaptörvény egyértelművé teszi: nem jogként, (bár a szociális biztonság alapjogi jellegét korábban is vitatták, és maga az Alkotmánybíróság sem tekintette valódi alapjognak, melyet több határozatban is kifejtett) hanem „csupán” államcélként tekint a szociális biztonságra. ${ }^{36}$ Míg ugyanis az Alkotmány 70/E. § szerint „A Magyar Köztársaság állampolgárainak joguk van a szociális biztonsághoz...,” az Alaptörvény rendelkezése nyomán az államnak csupán törekednie kell a szociális biztonság nyújtására. ${ }^{37}$ Többek szerint ez a változás visszalépést jelent az Alkotmányhoz képest, amely visszaminősíti a szociális biztonsághoz való jog jelentőségét. ${ }^{38}$ Figyelembe véve azonban, hogy az Alkotmánybíróság korábbi értelmezése során sem tekintett valódi alapjogként a szociális biztonsághoz való jogra, nem volt hova gyengíteni. Államcélként tekintettek rá eddig is, és az Alaptörvényben is ekként került megfogalmazásra, ${ }^{39}$ így ez a rendelkezés valójában az Alkotmánybíróság

\footnotetext{
${ }^{33}$ HAJDÚ József: A szociális biztonság jelentése és védelme az Alaptörvényben. In: Balogh Elemér (szerk.): A történeti alkotmánytól az Alaptörvényig. Jurisperitus, Szeged, 2015, 34.

34 BALOGH (2011a): i. m., 309.

${ }^{35}$ Az új szabályozási koncepcióról elsőként szólt a 23/2013. (IX. 25.) AB határozat, ABH 2013, 692. A szabályozás változásáról részletesebben lásd RÁcz Zoltán: A szociális biztonsághoz való jog Magyarországon a rendszerváltozás óta eltelt időszakban. Acta Universitatis Szegediensis: Acta juridica et politica, 2016, 535-542. [a továbbiakban: RÁcz (2016)]; TÉGLÁsı (2011): i. m.

${ }^{36}$ Az Alkotmánybíróság az Alaptörvény megalkotását követően született alábbi határozataiban a szociális biztonsághoz való jog államcélként való minősítéséről rendelkezik: 40/2012. (XII. 6.) AB határozat, $A B, 2012$, 229., 3217/2014. (IX. 22.) $A B$ határozat, $A B$ 2014, 2404., 28/2015. (IX. 24.) $A B$ határozat, 9/2016. (IV. 6.) $A B$ határozat.

${ }^{37}$ Lásd részletesebben JuHÁsz Gábor: A gazdasági és szociális jogok védelme az Alkotmányban és az Alaptörvényben. Fundementum, 2012/1, 44-48.; TÉGLÁsı András: A szociális biztonság alkotmányos védelme az Alaptörvény hatálybalépése előtt és után. Acta Humana, 2019/2, 85-106. [a továbbiakban: TÉGLÁsı (2019)]. (doi: 10.32566/ah.2019.2.5)

${ }^{38}$ Lásd például RAB Henriett: A nyugdíjbiztosítási ellátások fenntarthatóságának jogi garanciái, HVG-ORAC, Budapest, 2012, 43.

39 JAKAB András: Az új Alaptörvény keletkezése és gyakorlati következményei. HVG-ORAC, Budapest, 2011, 215.
} 
korábbi gyakorlatát foglalta alaptörvénybe. Mindazonáltal az a tény, hogy az Alaptörvény továbbra is rendelkezik e jogról, bizonyítja a fontosságát. Az azonban kétségtelen, hogy az államcélként való nevesítés szélesebb, de alkotmányos keretek között gyakorolható mozgásteret tesz lehetővé az államnak a szociális biztonsági rendszer kiépítése és müködtetése tekintetében. A taxatíve felsorolt esetek ${ }^{40}$ között határozza meg az Alaptörvény a rokkantság, fogyatékosság és önhibán kívül bekövetkezett munkanélküliség esetét, melynek bekövetkeztekor az egyének törvényben meghatározott támogatásra jogosultak. A támogatások formája és részletszabályai kapcsán a jogalkotó szabadsággal rendelkezik. A (2) bekezdés szerint pedig az állam szociális intézmények és intézkedések rendszere által teremti meg a szociális biztonságot hazánkban. A szociális biztonság tárgya kapcsán is változást hozott az Alaptörvény. Míg az Alkotmány a szociális biztonság megvalósításának eszközei között sorolta fel a társadalombiztosítás és a szociális intézmények rendszerét, addig az Alaptörvény eszközei között már nem szerepel a társadalombiztosítás rendszere, de magmaradt közöttük a szociális intézmények sora, illetve kibővült a szociális intézkedésekkel. A társadalombiztosítás eszközének elhagyása azonban felveti azt a problémát, hogy ezzel Magyarország megsérti a nemzetközi dokumentumokból - nevezetesen a Gazdasági, Szociális és Kulturális Jogok Nemzetközi Egyezségokmányának 9. cikkéből, az ILO 102. számú egyezményéből -, illetve az Európai Szociális Karta 12. cikkéből eredő kötelezettségét. ${ }^{41}$

Téglási András és Hoffman István megállapítása szerint összességében véve az Alaptörvény XIX. cikke nem eredményezett lényegesen más koncepciót a szociális biztonság alkotmányos védelme kapcsán az Alkotmánybíróság Alaptörvény előtti és utáni gyakorlatát összevetve. ${ }^{42}$ Alapvetően az új alkotmányos szabályozás a korábbi alkotmánybírósági gyakorlat Alaptörvénybe foglalásának feleltethető meg.

A fent leírtak alapján, a célcsoporti kör esetében alapvető fontosságú jognak tekintendő a szociális biztonsághoz való jog, - az alaptörvényi szabályozással hozott új szemléletmód, változás ellenére is - hiszen mind a fogyatékos, mind a megváltozott munkaképességü személyek számára elengedhetetlen a létfenntartásuk, megélhetésük biztosítása, illetve az azt elősegítő támogatások igénybevétele.

\subsection{A munkához való jog}

Végezetül, az Alaptörvény XII. cikke rendelkezik a munkához való jogról. E szociális jog, a szociális biztonsághoz való jogtól eltérően a szociális jogok első csoportjába tartozik, azaz alapjognak minősül. Az alapjognak minősülő szociális jogok visszavezethetők valamely klasszikus szabadságjogra. Jelen esetben a munkához

${ }^{40}$ Az Alkotmányhoz képest fordulatot hozott az Alaptörvény szociális biztonsághoz való jog alanyainak köre is, ugyanis míg az Alkotmány exemplifikatív módon sorolta fel a jogosultak körét, addig az Alaptörvény csak a taxációban szereplő alanyok számára biztosítja a szociális biztonsághoz való jogot.

41 RÁcz (2016): i. m., 538-539.

42 TÉGLÁSI (2019): i. m. 103-104.; HoffMAN István: A szociális segélyezés alkotmányos keretei - az Alkotmánybíróság döntéseire figyelemmel. In: Chronowski Nóra-Pozsár-Szentmiklósy Zoltán-Smuk Péter-Szabó Zsolt (szerk): A szabadságszerető embernek: Liber Amicorum István Kukorelli. Gondolat, Budapest, 2017, 483. 
való jog az egyéni cselekvési autonómia alapjogából ered. Ezeknek a jogoknak a védelme megegyezik a klasszikus alapjogok védelmével, melyek csak a szükségességi - arányossági teszt alapján korlátozhatók. ${ }^{43}$ Ezek alapján a munkához való jog erősebb szociális jognak minősül a szociális biztonsághoz való jognál, ellenben meglátásom szerint mindkét jog kiemelt jelentőséggel bír a célcsoporti kör tekintetében. $E$ jog elsődleges jelentése értelmében az embereknek joguk van az állam termelő és szolgáltató tevékenységeiben részt venni, és joguk van az ebből származó haszonból való részesüléshez. ${ }^{44}$

A XII. cikk 1) bekezdése összetett módon biztosít jogosítványt, és ír elő egyben kötelezettséget is az állampolgárok számára. Eszerint mindenkinek joga van a munka és foglalkozás szabad megválasztásához (illetve a vállalkozáshoz), ugyanakkor mindenki köteles képességei és lehetőségei szerint munkát végezni - amely rendelkezés új elem az Alaptörvényben. Az Alaptörvény, a szociális biztonsághoz való joghoz hasonlóan, e jog tekintetében is változást hozott, az Alkotmánybíróság gyakorlatával összhangban. Korábban az Alkotmány 70/B.§ egy mondaton belül rendelkezett a munkához való jog pozitív (munkához való jog mint szociális jog - a munka megszerzése és megtartása) és negatív (foglalkozás szabad megválasztása) oldaláról, melyek közül az Alkotmánybíróság alanyi jogként kizárólag a negatív oldalt ismerte el, és részesítette alkotmányos védelemben. ${ }^{45} \mathrm{~A}$ munkához való jog alaptörvényi újraszabályozása megerősítette az Alkotmánybíróság gyakorlatát, és a XII. cikkben már csak a munkához való jog negatív oldalát rögzíti alanyi jogként. A munkavégzést a jogalkotó azonban nemcsak mindenkinek biztosítandó jogként határozza meg, hanem azt a társadalom és az állam müködésének zálogaként egyben elvárásként is ${ }^{46} \mathrm{~A}$ munkához való jog pozitív oldalát a jogalkotó a (2) bekezdés keretében relatív állami kötelezettségként, államcélként szabályozza, - melyet e jog intézményvédelmi oldalának is nevezhetünk - miszerint az államnak törekednie kell a munkavégzés feltételeinek - megfelelő foglalkoztatáspolitika, munkahelyteremtés - megteremtésére. ${ }^{47}$ Ebben a vonatkozásban a munkához való jog kettős természetủ, azaz az állam nemcsak tartózkodni köteles e jog gyakorlása tekintetében, hanem aktívan is fel kell lépnie. Az állami kötelezettség szerves részét képzi az egyenlő bánásmód elvénél taglalt hátrányos megkülönböztetés-mentesség érvényre juttatása, miszerint a munkához való jogot megkülönböztetés nélkül biztosítani kell mindenki számára. ${ }^{48}$

A munkához való jog alanyai tekintetében megjegyzést érdemel, hogy meg kell különböztetni a fogyatékos személyek foglalkoztatásától a cselekvőképtelen személyek foglalkoztatását. Azt gondolnánk, hogy egy fogyatékos személy cselekvőképtelen is egyben, ami sok esetben igaz is, de nem feltétlenül minden esetben.

\footnotetext{
43 BALOGH (2011a): i. m., 308.

44 RÁCz Zoltán: Munkához való jog. In: Lamm Vanda (szerk.): Emberi jogi enciklopédia. HVG-ORAC, Budapest, 2018, 501-508.

${ }^{45}$ 21/1994. (IV. 16.) AB határozat, ABH 1994, 117. és a Wolters Kluwer jogtárának XII. cikkhez füzött kommentárja alapján.

${ }^{46}$ A XII. cikk indoklása alapján.

47 JuHÁsz: i. m., 35-37.; BALOGH (2011): i. m., 313-315.

${ }^{48}$ RÁCZ (2018): i. m., 504.
} 
Tehát nem lesz valaki automatikusan cselekvőképtelen amiatt, hogy valamilyen fogyatékossággal él. Az Alkotmánybíróság 39/2011. (V. 31.) AB határozatában (ABH 2011, 265) azt vizsgálta, hogy fogyatékosság miatt cselekvőképtelen nagykorú személyek esetén a munkához való alapjog érvényesüléséhez szükséges garanciák hogyan érvényesülnek. Míg az Alkotmány kizárólag a foglalkozás szabad megválasztásának jogáról rendelkezett, addig az Alaptörvény emellett kötelezettségként is elöírja a munkavégzést, a saját képességekhez és lehetőségekhez mérten. Így ha egy fogyatékos vagy fogyatékosság miatt cselekvőképtelen személy képes és szeretne munkát vállalni, akkor ahhoz joga van, - sőt köteles is dolgozni az Alaptörvény rendelkezése szerint - így biztosítani kell annak lehetőségét. A fent említett $A B$ határozat 1.1. pontjában az Alkotmánybíróság megállapította, hogy „,...a belátási képesség tartós és teljes mértékü hiánya az önálló munkaviszony-létesités természetes akadálya lehet, ugyanakkor a cselekvőképtelen személyek teljes kizárása a munkaviszony típusú foglalkoztatásból adott esetben alkotmányossági aggályokat vethet fel." Ebből következően tehát az az állításom, miszerint a munkaképes és dolgozni akaró cselekvőképtelen személy számára is biztosítani kell a munkavégzés lehetőségét, igazolható. Továbbá maga az $A B$ határozat is kimondta, hogy a jogi szabályozásnak törekednie kell a cselekvőképtelen személyek munkavállalási lehetőségeinek és esélyeinek növelésére. Ennek a kötelezettségnek igyekszik eleget tenni az Alaptörvény a (2) bekezdésben foglalt rendelkezésével - „minden munkaképes ember dolgozhasson."

A következőkben e három alapjog érvényesülését és további védelmét biztosító jogszabályokat elemzem, melyek a védelem munkajogi és szociális jogi vetületét alkotják.

\title{
3. Munkajogi és szociális jogi védelem
}

\subsection{Az egyenlő bánásmódról és esélyegyenlőség előmozditásáról szóló törvény által biztosított védelem}

Az Alaptörvény rendelkezéseit követöen, mondhatni a legfontosabb általános szintü, védelmi célú szabályozást az egyenlő bánásmódról és esélyegyenlőség előmozdításáról szóló törvény ${ }^{49}$ (a továbbiakban: Ebktv.) tartalmazza a fogyatékos és megváltozott munkaképességủ személyek kapcsán. Ez a szándék már a törvény elején rögzített, jogalkotói célban is megfogalmazódik. Eszerint

\begin{abstract}
„Az Országgyülés elismerve minden ember jogát ahhoz, hogy egyenlö méltóságú személyként élhessen, azon szándékától vezérelve, hogy hatékony jogvédelmet biztositson a hátrányos megkülönböztetést elszenvedök számára, kinyilvánitva azt, hogy az esélyegyenlőség és a társadalmi felzárkózás elömozditása elsősorban állami kötelezettség, tekintettel az Alaptörvény II. és XV. cikkére, valamint a Köztársaság nemzetközi kötelezettségeire és az európai közösségi jog vívmányaira,"
\end{abstract}

${ }^{49}$ Az egyenlő bánásmódról és esélyegyenlőség előmozdításáról szóló 2003. évi CXXV. törvény. 
megalkotja e törvényt. Tehát az e törvényben foglalt rendelkezések az Alaptörvényből eredő állami kötelezettséget, az esélyegyenlőség megteremtését és a társadalmi felzárkózást szolgálják.

A törvény meghatározza azokat az eseteket, amelyek az egyenlő bánásmód megsértését jelentik, közvetlen és közvetett hátrányos megkülönböztetést idézve elő..$^{50}$ Ezekre az esetekre vonatkozóan a törvény deklarálja, hogy a hátrányos megkülönböztetést elszenvedett személy milyen eszközökkel élhet, vagyis milyen jogkövetkezmények füződnek az Ebktv. rendelkezéseinek megsértéséhez.. ${ }^{51}$ A jogsértések között az Ebktv. külön is rendelkezik a foglalkoztatás ${ }^{52}$ és szociális biztonság ${ }^{53}$ körében elkövetett jogsértésekröl. Foglalkoztatás körében a munkáltató különösen akkor sérti meg az egyenlő bánásmód követelményét, ha azt a munkához való hozzájutásban, a munkaviszony létesítésével vagy a jogviszony fennállásával összefüggésben, vagy a munkafeltételek kapcsán követi el. Csak az arányos, megfelelően alátámasztott indokon alapuló megkülönböztetés jogos, illetve a törvény értelmében előnyben részesítési kötelezettség is előírható, meghatározott munkavállalók érdekében. A szociális biztonságot illetően a célcsoporti körrel szembeni jogsértés a szociális ellátás igénylése vagy biztosítása tekintetében valósulhat meg.

A vizsgált célcsoport foglalkoztatása és egyenlő társadalmi részvétele tekintetében az Ebktv. fent megnevezett rendelkezései az Alaptörvény XV. cikkének megfelelő részletszabályokat tartalmazzák, megerősítve ezáltal az egyenlő bánásmódra vonatkozó alapjogi védelmet. A rendelkezések egyértelműen meghatározzák, hogy megfelelő indok hiányában biztosítani kell a fogyatékos és megváltozott munkaképességű személyeknek is a foglalkoztatás lehetőségét, sőt, esetükben szükség szerint előnyben részesítés is megengedett. Az Ebktv. rendelkezései mindezek alapján megfelelő védelmet biztosítanak a célcsoporti kör számára.

\subsection{A Munka Törvénykönyvének a célcsoportot érintő, védelmi rendelkezései}

Az Ebktv.-t követően a Munka törvénykönyvének ${ }^{54}$ (a továbbiakban Mt.) azon rendelkezéseit veszem górcső alá, melyek a célcsoporti kör foglalkoztatása kapcsán valamilyen garanciát, védelmet ${ }^{55}$ biztosítanak a számukra. Az Mt. az Ebktv.-vel szemben azonban csak meghatározott számú releváns rendelkezést tartalmaz.

Az Mt. 51. § (5) bekezdése kimondja, hogy „A fogyatékossággal élő személy foglalkoztatása során gondoskodni kell az ésszerü alkalmazkodás feltételeinek biztosításáról." Ugyanakkor az Mt. nem részletezi azt, hogy pontosan mit ért észszerü alkalmazkodás alatt, így annak értelmét a bírói gyakorlatnak kell kialakítania.

Az Mt. 53. § (3) bekezdés d) pontja értelmében „A munkavállaló hozzájárulása nélkül nem kötelezhető más helységben végzendő munkára, ha a rehabilitációs

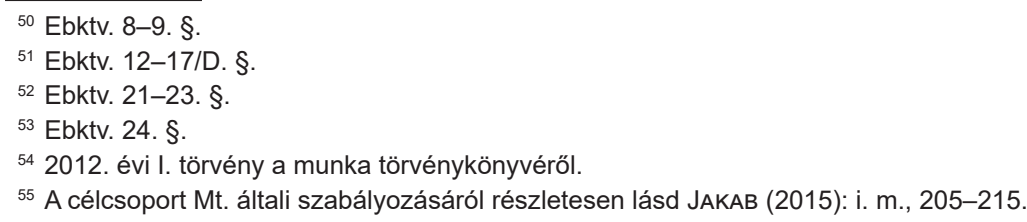


szakértői szerv legalább ötven százalékos mértékü egészségkárosodását megállapította." Eszerint a megváltozott munkaképességü személy munkaszerződéstől eltérő foglalkoztatása korlátozott, azt a munkavállaló hozzájárulása nélkül nem alkalmazhatja a munkáltató.

A következő releváns rendelkezés a 66. § (7) bekezdése, amely felmondási védelmet biztosít a megváltozott munkaképességü személyek számára. Ennek értelmében

„A munkáltató a rehabilitációs ellátásban vagy rehabilitációs járadékban részesülő munkavállaló munkaviszonyát a munkavállaló egészségi okkal összefüggő képességével indokolt felmondással akkor szüntetheti meg, ha a munkavállaló eredeti munkakörében nem foglalkoztatható tovább és a munkavállaló számára állapotának egészségi szempontból megfelelő munkakört nem tud felajánlani, vagy a munkavállaló a felajánlott munkakört alapos ok nélkül nem fogadja el."

Ez a felmondási védelem felmondási korlátot jelent, ami kizárólag a munkavállaló egészségi okkal összefüggő képességével indokolt felmondással szemben nyújt védelmet. Ez a korlát azonban a megváltozott munkaképességű személyeknek fontos védelmet jelent, ugyanis ha az egészségkárosodást követően továbbra is képes dolgozni valaki, akkor a munkáltatónak továbbra is biztosítani kell számára a munkavégzés lehetőségét.

Végezetül a 212. § bír jelentőséggel a fogyatékos személyek tekintetében, amenynyiben a fogyatékosság cselekvőképességüket is érinti. A 212. §-ban úgy rendelkezik az Mt., hogy
„(1) A cselekvőképtelen vagy a cselekvőképességében a munkaviszonnyal össze- függő ügycsoportban részlegesen korlátozott munkavállaló csak olyan munkakörre létesíthet munkaviszonyt, amelyet egészségi állapotánál fogva tartósan és folyamato- san képes ellátni. (2) A munkavállaló munkakörét az ahhoz tartozó feladatok részletes leírásával kell meghatározni. A munkavállalóra vonatkozó egészségügyi alkalmassá- gi vizsgálat kiterjed a részletes munkaköri feladatok ellátására. (3) A munkavállaló munkavégzését folyamatosan és oly módon kell felügyelni, hogy az az egészséges és biztonságos munkafeltételek megtartását biztosítsa. (4) A munkavállalóra a fiatal munkavállalóra vonatkozó rendelkezések megfelelően irányadók azzal, hogy kárté- rítésre vagy sérelemdíj megfizetésére nem kötelezhető."

Ezzel a rendelkezéssel a jogalkotó megteremti a munkavállalás elvi lehetőségét a mentálisan sérült személyek számára is. A jogalkotó e munkavállalók megfelelő körülmények és feltételek közötti foglalkoztatásának garantálása érdekében elöírja, hogy részletekbe menően kell meghatározni a munkavállaló által elvégzendő feladatokat, illetve gondoskodni kell a megfelelő munkafeltételekről és azok ellenörzéséröl.

Megállapítható, hogy az Mt. is több védelmi rendelkezést tartalmaz a fogyatékos és megváltozott munkaképességü személyek kapcsán. Azonban, Jakab Nórával egyet értve, a nem egységes fogalomhasználat e két személyi kategória külön kezelését eredményezi, amely bizonyos esetben jogosnak tủnik, ellenben például az észszerű alkalmazkodás követelményét mindkét alanyi kör esetén alkalmazni kellene. 


\subsection{A célcsoport védelmét szolgáló egyéb törvényi rendelkezések}

Az Mt. és az Ebktv. mellett több olyan törvény létezik hazánkban, amely az Alaptörvényböl eredő alapjog megvalósulását biztosítva került megalkotásra. Ide tartozik a szociális igazgatásról és szociális ellátásokról szóló törvény, ${ }^{56}$ amely meghatározza a szociális biztonság megteremtése és megőrzése érdekében az állam által biztosított egyes szociális ellátások formáit, szervezetét, a szociális ellátásokra való jogosultság feltételeit, valamint érvényesítésének garanciáit.

A fogyatékos személyek jogairól és esélyegyenlőségük biztosításáról szóló törvény ${ }^{57}$ a fogyatékos személyek érdekében hátrányaik enyhítését, esélyegyenlőségük megalapozását, illetve a társadalom szemléletmódjának alakítását szolgálja. A törvény célja a fogyatékos személyek jogainak, a jogok érvényesítési eszközeinek meghatározása, továbbá a fogyatékos személyek számára nyújtandó, komplex rehabilitáció szabályozása, és mindezek eredményeként a fogyatékos személyek esélyegyenlőségének, önálló életvitelének és a társadalmi életben való aktív részvételének biztosítása.

Végül a megváltozott munkaképességú személyek ellátásáról szóló törvény ${ }^{58}$ a megváltozott munkaképességű személyek kapcsán szabályoz védelmi rendelkezéseket. E törvény célja a megváltozott munkaképességű személyek megmaradt, fejleszthető képességeire épülő, foglalkoztatás-központú rehabilitációja, társadalmi reintegrációjának, foglalkoztatásának elősegítése, továbbá a kieső jövedelem miatti keresetpótlás.

\section{Záró gondolatok}

A hátrányos helyzetű személyek, azon belül a fogyatékos és megváltozott munkaképességủ személyek is ugyanúgy társadalmunk tagjai, még ha a „másságuk” alapján határozzuk is meg őket. Ezeket az embereket is megilletik az alkotmányos alapjogok, melyek közül bizonyos alapjogoknak foglalkoztatásuk kapcsán kiemelkedő jelentősege van, nevezetesen az egyenlő bánásmódhoz, a szociális biztonsághoz és a munkához való jognak. Ezek a jogok biztosítják ugyanis számukra azt, hogy ők is ugyanolyan mértékben jogosultak a jóllétre, a megfelelő életkörülményekre, továbbá jogosultak munkát vállalni, dolgozni, méghozzá hátrányos megkülönböztetés nélkül. Esetükben előnyben részesítés is alkalmazható, amennyiben az indokolt, és az őket megillető jogok így érvényesíthetők.

A bevezetőben meghatározott hipotézisem úgy vélem alátámasztásra került, az ismertetett alapjogok maximálisan igazolják a fogyatékos és megváltozott munkaképességủ személyek munkához való hozzáférésének jogát, illetve egyenjogúságukat. Mindezek a jogok alapvető jelentőséggel bírnak a munkajogi és szociális jogi

\footnotetext{
${ }^{56}$ A szociális igazgatásról és szociális ellátásokról szóló 1993. évi III. törvény.

${ }^{57}$ A fogyatékos személyek jogairól és esélyegyenlőségük biztosításáról szóló 1998. évi XXVI. törvény.

${ }^{58}$ A megváltozott munkaképességű személyek ellátásáról és egyes törvények módosításáról szóló 2011. évi CXCl. törvény.
} 
védelmük esetében is. Az Alaptörvényben lefektetett jogok a munkajogi és szociális jogi jogszabályok által nyernek tartalmat.

A szociális farm olyan modell, amely azokat a hiányosságokat kívánja kezelni, azt az ürt szeretné kitölteni, amely e személyeket érinti. Így megkülönböztetésüket, társadalmi kirekesztésüket, a munkaerőpiacról való kiszorításukat, a munkavállalás lehetőségének jelentős korlátozottságát orvosolja a farm azáltal, hogy integrálja őket, támogató farmszolgáltatást biztosít számukra mezőgazdasági tevékenységek végzése által, ideértve foglalkoztatásukat is, melyet - az elemzett alapjogok, föként a munkához való jog alapján - számukra is biztosítani kell. A farmszolgáltatásnak köszönhetően az emberek is a társadalom hasznos tagjának érezhetik magukat, nem beszélve arról a jelentős pozitív fejlődési tendenciáról, amely a farm nyújtotta segitségnek köszönhetö. ${ }^{59}$ 